\title{
Chrysin Induced Cell Apoptosis and Inhibited Invasion Through Regulation of TETI Expression in Gastric Cancer Cells [Corrigendum]
}

Zhong X, Liu D, Jiang Z, et al. Onco Targets Ther. 2020;13:3277-3287

The authors have advised Figure 2E on page 3281 is incorrect. The migration of cells after chrysin treatment between $12 \mathrm{~h}$ and $24 \mathrm{~h}$ were very close, so the error was not identified. A recent check of the original data by the authors found this error. The correct Figure 2 is shown below.

The authors apologize for this error and advise it does not affect the results of the paper.
A

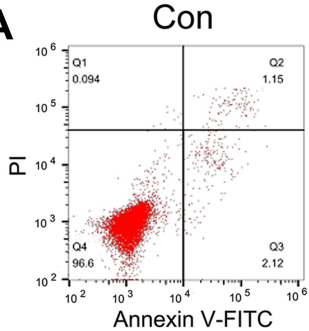

C

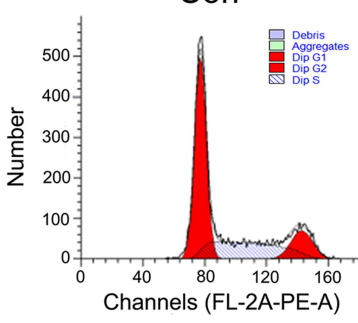

E
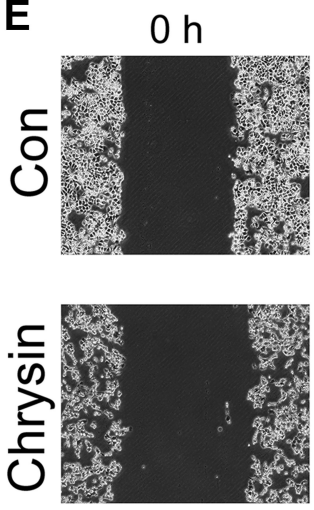
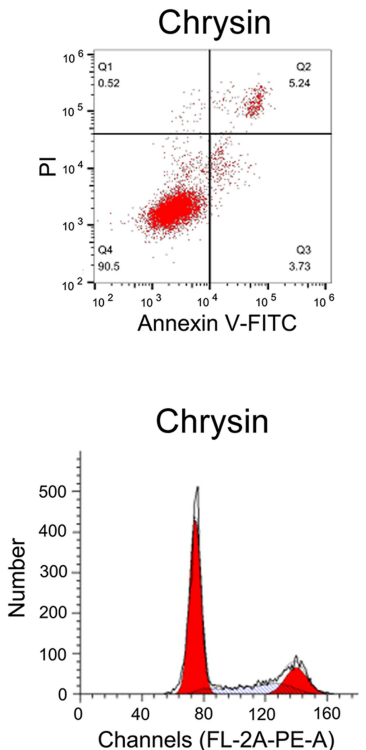

B
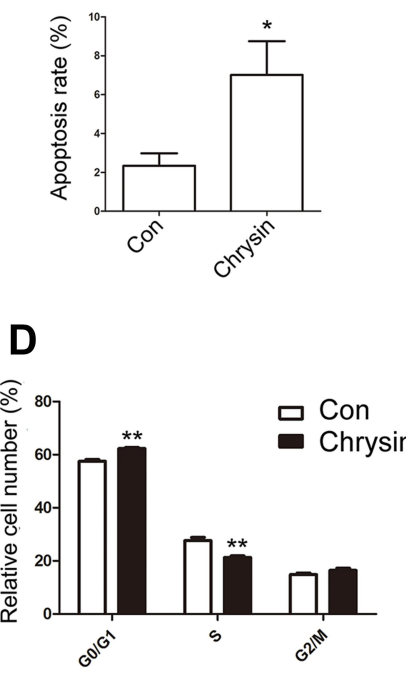

G

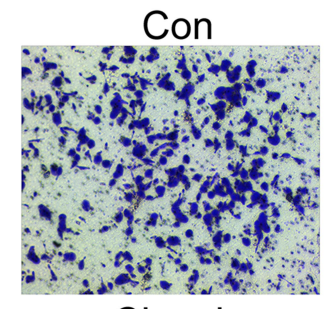
Chrysin

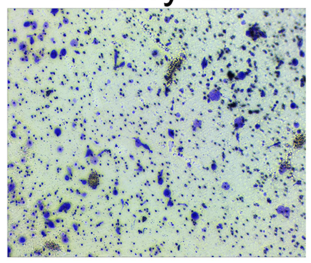

H

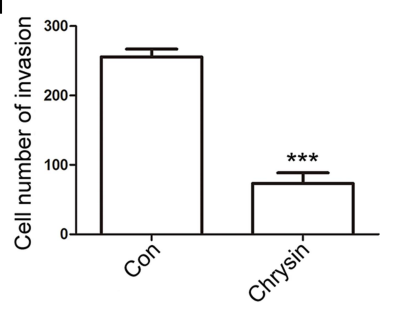

$\mathbf{F}$
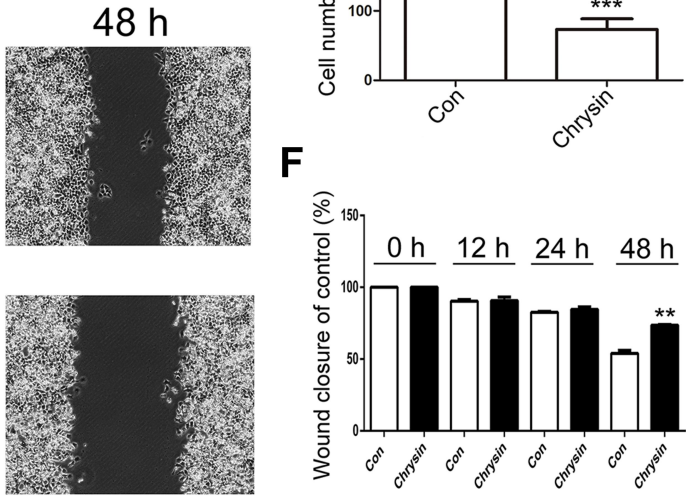

Figure 2 Analysis of cell apoptosis, cell cycle, and cell migration and invasion in GC cells. Cell apoptosis was analyzed after treatment with Chrysin (A). Statistical analysis of the percentage of cell apoptosis (B). The cell cycle was analyzed after treatment with Chrysin (C). Statistical analysis of the percentage of cells in the major phases of the cell cycle (D). Cell migration was analyzed after treatment with Chrysin (b). Statistical analysis of cell migration with wound closure assay (F). The cell invasion was analyzed after treatment with Chrysin (G). Statistical analysis of the cell invasion $(\mathbf{H}) . *(p<0.05)$, $* *(p<0.0 \mathrm{I})$ and $* * *(p<0.005)$ indicate statistically significant differences. 


\section{Publish your work in this journal}

OncoTargets and Therapy is an international, peer-reviewed, open access journal focusing on the pathological basis of all cancers, potential targets for therapy and treatment protocols employed to improve the management of cancer patients. The journal also focuses on the impact of management programs and new therapeutic

Submit your manuscript here: https:/www.dovepress.com/oncotargets-and-therapy-journal agents and protocols on patient perspectives such as quality of life, adherence and satisfaction. The manuscript management system is completely online and includes a very quick and fair peer-review system, which is all easy to use. Visit http://www.dovepress.com/ testimonials.php to read real quotes from published authors. 